\title{
Behavior of Mercury in the Formic Acid Vent Condenser-Interim Report
}

by

J. R. Zamecnik

Westinghouse Savannah River Company

Savannah River Site

Aiken, South Carolina 29808
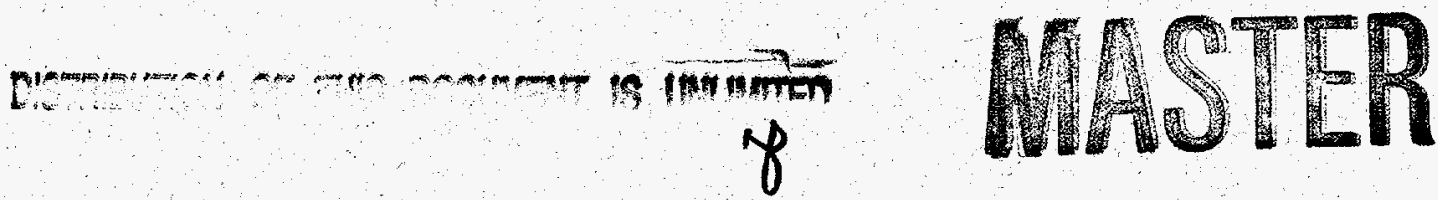

DOE Contract No. DE-AC09-89SR18035

This paper was prepared in connection with work done under the above contract number with the U. S. Department of Energy. By acceptance of this paper, the publisher and/or recipient acknowledges the U.S. Government's right to retain a nonexclusive, royalty-free license in and to any copyright covering this paper, along with the right to reproduce and to authorize others to reproduce all or part of the copyrighted paper. 


\section{DISCLAIMER}

This report was prepared as an account of work sponsored by an agency of the United States Government. Neither the United States Government nor any agency thereof, nor any of their employees, makes any warranty, express or implied, or assumes any legal liability or responsibility for the accuracy, completeness, or usefulness of any information, apparatus, product, or process disclosed, or represents that its use would not infringe privately owned rights. Reference herein to any specific commercial product, process, or service by trade name, trademark, manufacturer, or otherwise does not necessarily constitute or imply its endorsement, recommendation, or favoring by the United States Government or any agency thereof. The views and opinions of authors expressed herein do not necessarily state or reflect those of the United States Government or any agency thereof.

This report has been reproduced directly from the best available copy.

Available to DOE and DOE contractors from the Office of Scientific and Technical Information, P.O. Box 62, Oak Ridge, TN 37831; prices available from (615) 576-8401.

Available to the public from the National Technical Information Service, U.S. Department of Commerce; 5285 Port Royal Road, Springfield, VA 22161. 


\section{DISCLAMIER}

Portions of this document may be illegible in electronic image products. Images are produced from the best available original document. 


\section{to \\ Record Indexing \\ Required with all records submitted to D\&RA \\ 69066}

Print or type in black thik.

Transmittal No. R063985

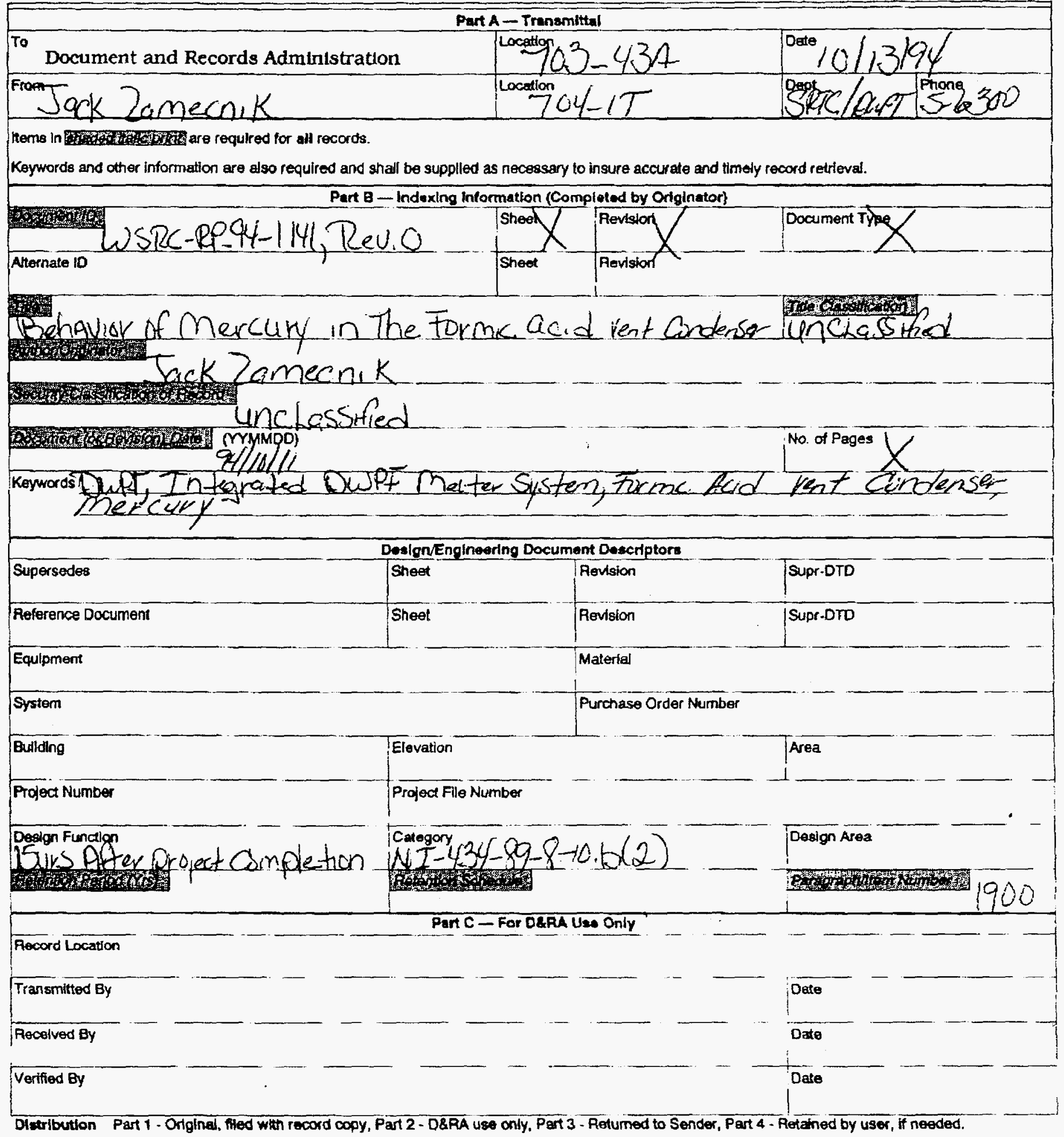


CSR 14-357 \{Rev 3-30-93)

INFORMATION ONLY

Storen: 26-12301

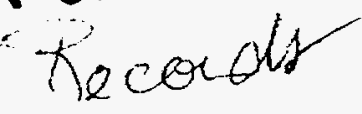

\section{Westinghouse Savannah River Company Document Approval Sheet}

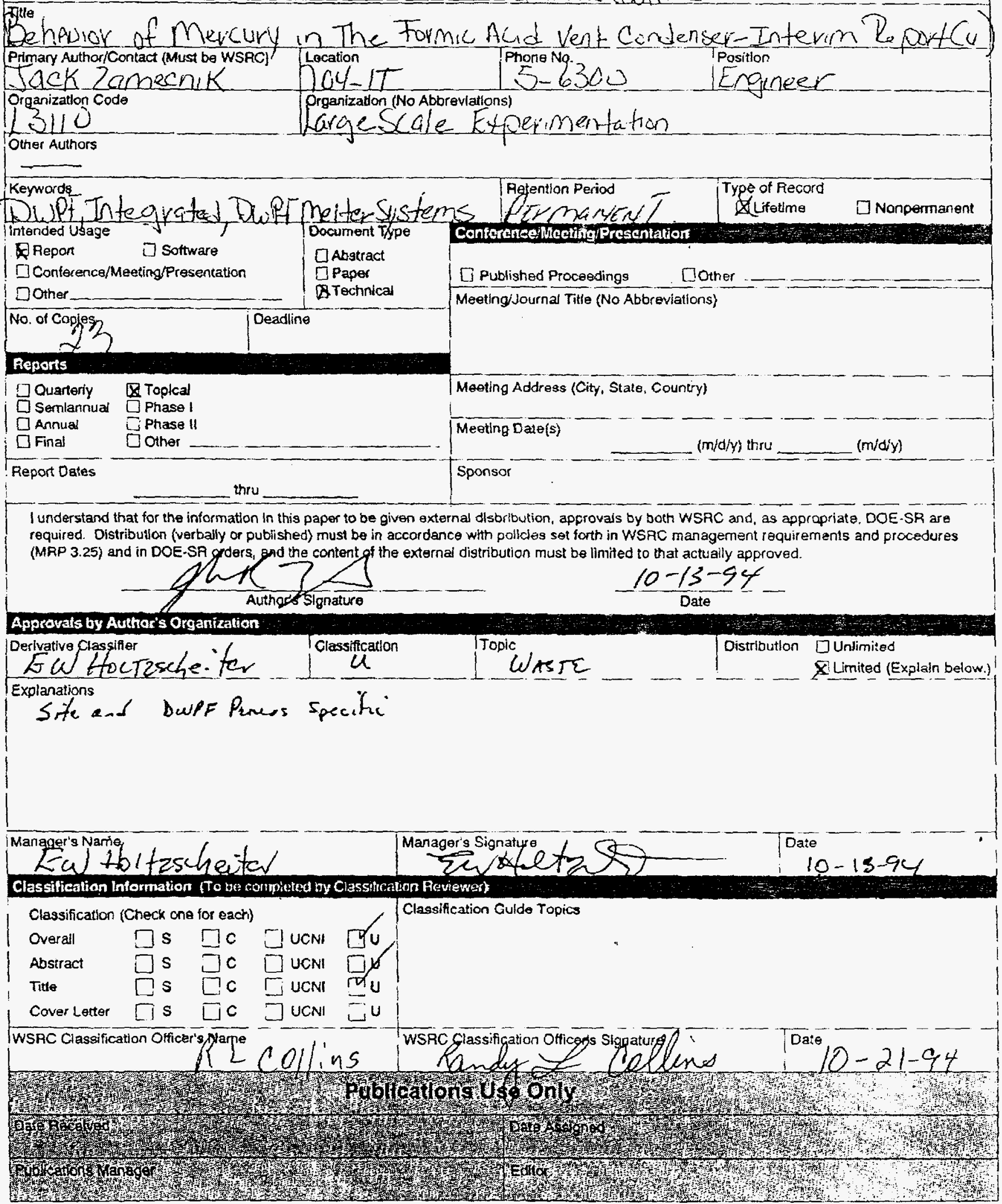


WSRC-RP-94-1141, Rev. 0

\section{DISTRIBUTION:}

L. M. Papouchado, 773-A

E. W. Holtzscheiter, 773-A

D. A. Crowley, 704-1T

E. F. Duhn, 773-A

L. F. Landon, 704-T

C. T. Randall, 704-T

R. E. Eibling, 704-T

T. L. Fellinger, 704-1T

C. W. Hsu, 704-1T

N. D. Hutson, 704-1T
N. H. Kuehn, 704-T

D. P. Lambert, 704-1T

K. M. Marshall, 704-1T

D. H. Miller, 704-1T

R. L. Minichan, 704-1T

H. B. Shah, 704-1T

M. E. Smith, 704-1T

S. R. Young, 704-27S

J. R. Zamecrik, 704-1T

TIM, 703-46A (4) 


\section{BEHAVIOR OF MERCURY IN THE FORMIC ACID VENT CONDENSER- INTERIM REPORT (U)}

Author: J.R.Zamecnik

Publication Date: October 11, 1994
Keywords: DWPF, Integrated DWPF Melter System, Formic Acid Vent Condenser, Mercury

Retention: Permanent

EW bloctzak

E. W. Holtzscheiter

Authorized Derivative Classifier

Westinghouse Savannah River Company

Savannah River Site

Aiken, SC 29808

Prepared for the U.S. Department of Energy under contract No. DE-AC09-89SR18035

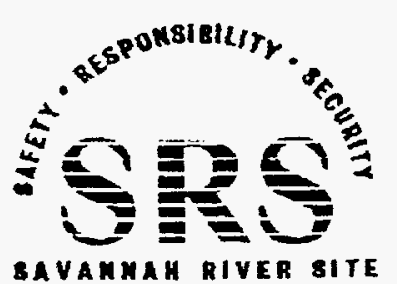


WSRC-RP-94-1141, Rev. 0

This report was prepared by Westinghouse Savannah River Company (WSRC) for the United States Department of Energy under Contract No. DE-AC09-89SR18035 and is an account of work performed under that contract. Neither the United States Department of Energy, nor WSRC, nor any of their employees makes any warranty, expressed or implied, or assumes any legal liability or responsibility for the accuracy, completeness, or usefulness, of any information, apparatus, or product or process disclosed herein or represents that its use will not infringe privately owned rights. Reference herein to any specific commercial product, process, or service by trademark, name, manufacturer or otherwise does not necessarily constitute or imply endorsement, recommendation, or favoring of same by WSRC or by the United States Government or any agency thereof. The views and opinions of the authors expressed herein do not necessarily state or reflect those of the United States Government or any agency thereof. 
WSRC-RP-94-1141, Rev. 0

APPROVALS

Management Approvals:

Eabbetzaheut 10/12/94

E. W. Holtzscheiter, Manager, Defense Waste Processing Technology, SRTC

Covid A. Combe 10/1194

D. A. Crowley, Manager, Large Scale Experimentation Group, DWPT, SRTC

Technical Review:

Leviditellinger $10 / 12 / 94$

T. L. Fellinger, Large Scale Experimentation Group, DWPT, SRTC

Author:

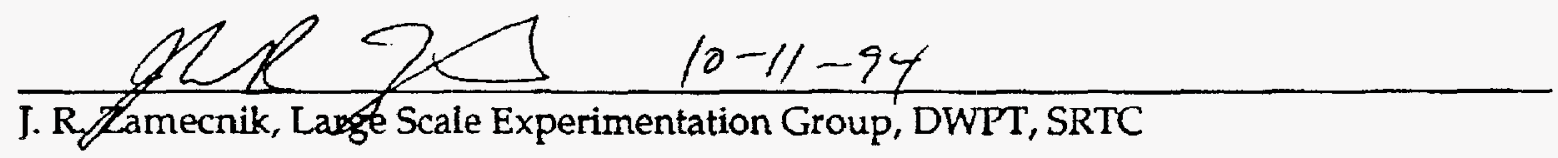

iii 


\section{TABLE OF CONTENTS}

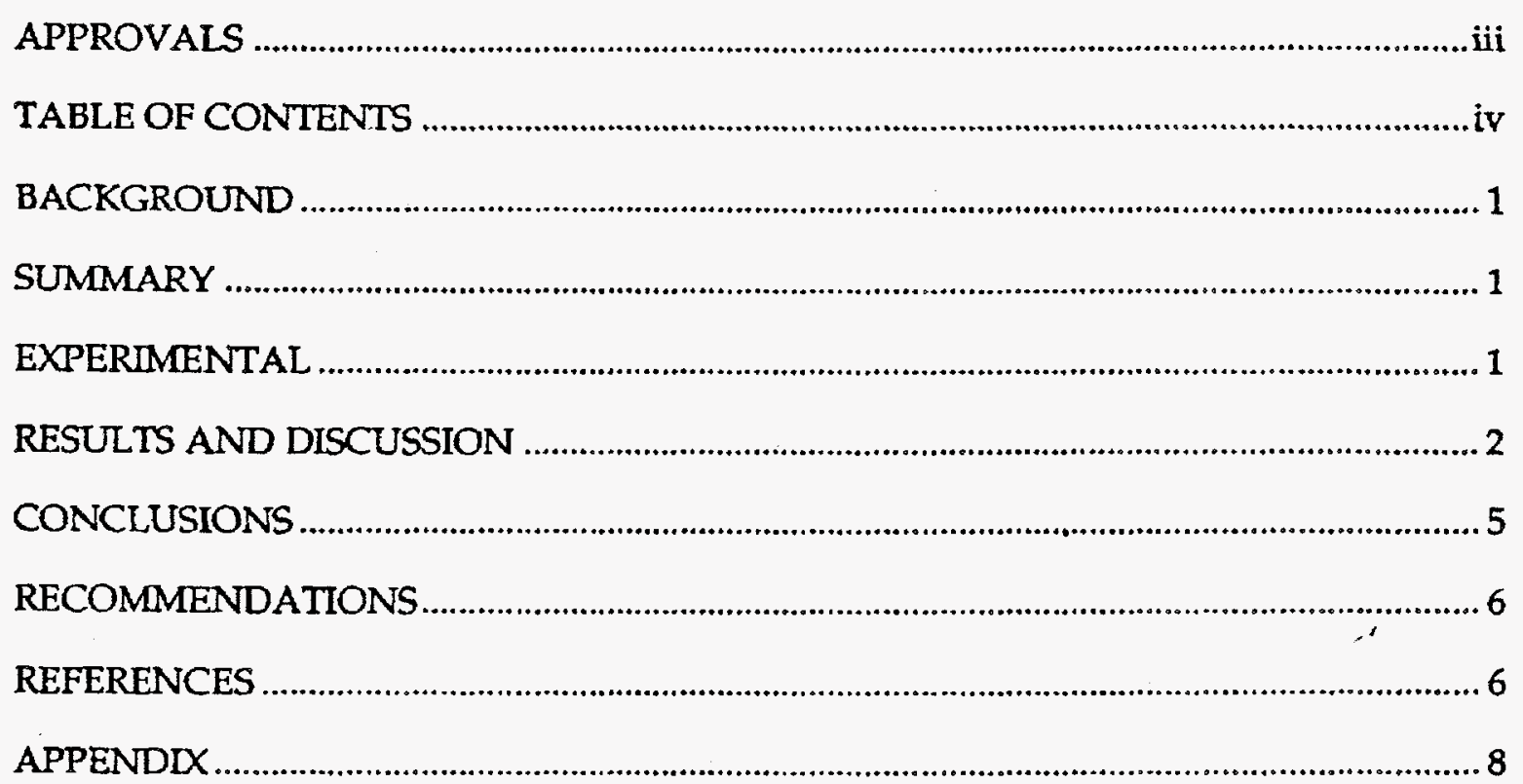


WSRC-RP-94-1141, Rev. 0

\section{BACKGROUND}

The performance of the DWPF Formic Acid Vent Condenser is the subject of DWPF Technology Issue 4.2 "Behavior of Mercury in the FAVC." The Formic Acid Vent Condenser (FAVC) is a chilled water condenser with a High Efficiency Mist Eliminator (HEME) and is designed to cool to $10^{\circ} \mathrm{C}$ the offgas from the Sludge Receipt and Adjustment Tank (SRAT), Slurry Mix Evaporator (SME), Melter Feed Tank (MFT), Recycle Collection Tank (RCT), and the Precipitate Reactor Bottoms Tank (PRBT). By cooling to $10^{\circ} \mathrm{C}$, water vapor is removed such that it will not condense downstream in the Process Vessel Vent Header, and the mercury content should be reduced to saturation at $10^{\circ} \mathrm{C}$. Mercury emissions from DWPF are limited by an environmental permit; ${ }^{1}$ in this permit it is assumed that the mercury concentration exiting the FAVC does not exceed saturation at the exit temperature (which is assumed to be $10^{\circ} \mathrm{C}$ except during peak $\mathrm{NO}_{\mathbf{x}}$ evolution).

To determine if the mercury content of the offgas exiting the FAVC will be at or below saturation, measurements of the mercury concentration in the offgas were perfórmed during the BL1 and PX6 runs of the IDMS. During BL1, the concentration of mercury at the inlet to the FAVC was also measured. These tests were conducted without the HEME.

The performance of the FAVC with the HEME and with the ammonia scrubber will be tested during the PX7 run of the IDMS.

\section{SUMMARY}

The concentrations of mercury at the FAVC inlet and exit were measured during the BL1 and PX6 runs of the Integrated DWPF Melter System (IDMS) with the HEME bypassed and without the ammonia scrubber. The results show that mercury concentrations of approximately 2.6-12.7 (mean $=6.2$ ) times saturation occur at the FAVC exit. The concentration of mercury at the SRAT condenser exit was found to be 10 times the saturation value.

FAVC exit mercury concentrations of 6.2 times saturation would result in DWPF emitting up to $438 \mathrm{lb} / \mathrm{yr}$ of mercury at $100 \%$ attainments, which is in excess of the permit limit of $175 \mathrm{lb} / \mathrm{yr}$. However, operation of the FAVC with the HEME should reduce the mercury emissions. The addition of the ammonia scrubbers should also reduce the mercury emissions since the nitric acid used to scrub ammonia should also scrub mercury.

\section{EXPERIMENTAL}

The concentration of mercury in the offgas was measured by extracting samples from the offgas system. These samples were passed through impingers (bubblers) to absorb the mercury. The gas samples were first passed through two impingers containing $2 \mathrm{M}$ $\mathrm{NaOH}$ to remove most of the $\mathrm{NO}_{\mathbf{x}}$. It was then passed through three impingers 
containing 1.5-4 (w/v)\% $\mathrm{KMnO}_{4}$ in $10(\mathrm{v} / \mathrm{v}) \% \mathrm{H}_{2} \mathrm{SO}_{4}$. The use of $\mathrm{KMnO}_{4}$ in $\mathrm{H}_{2} \mathrm{SO}_{4}$ has been described as the most effective method for absorbing elemental mercury, mercury compounds (except organomercury compounds), and particulate mercury. The mercury is oxidized to form $\mathrm{Hg}^{+2}$. A removal efficiency of $90-96 \%$ for a single impinger and $99 \%$ for two or more impingers has been reported. 2,3,4,5,6

In the presence of oxidizing gases such as $\mathrm{SO}_{2}$ or $\mathrm{NO}_{x}$ pretreatment of the gas sample is necessary to preserve the absorbing ability of the $\mathrm{KMnO}_{4} / \mathrm{H}_{2} \mathrm{SO}_{4}$ absorbent. ${ }^{3}$ For $\mathrm{SO}_{2}$, the use of acidic $\mathrm{H}_{2} \mathrm{O}_{2}$ is recommended. Caustic ( $\mathrm{NaOH}$ ) may also be used, but it will absorb some of the mercury present and convert it to $\mathrm{HgO}$. However, for this work, caustic was used since the impingers containing the caustic were also analyzed for mercury.

The analysis of the impinger samples was performed by Vapor Generation Apparatus (VGA) (cold vapor) atomic absorption (AA) spectroscopy by the DWPT laboratory at TNX. The caustic impinger solutions were treated with acidic permanganate to oxidize all the mercury to $\mathrm{Hg}^{+2}$ and then the mercury was reduced to elemental $\mathrm{Hg}$ by hydroxylamine before measurement on the AA. The $\mathrm{KMnO}_{4} / \mathrm{H}_{2} \mathrm{SO}_{4}$ impinger solutions were also treated with hydroxylamine before measurement on the AA.

\section{RESULTS AND DISCUSSION}

Sampling for mercury at the exit of the FAVC (without the HEME or ammonia scrubber) was conducted during the BL1 (6/90) and PX6 (12/93) runs of the IDMS. In the BL1 run, sampling at the FAVC inlet was also performed. The BL1 run used the formic acid flowsheet, whereas the PX6 run used the nitric acid flowsheet. Sampling in BL1 was performed during the formic acid reflux period, during which most of the mercury is stripped from the sludge. In PX6, sampling was done during the Precipitate Hydrolysis Aqueous (PHA) addition. Sampling during nitric acid addition was not performed since mercury is not evolved during this phase.

The concentrations of mercury in the samples taken during BLI and PX6 are shown in Figures 1 and 2, respectively. The data show that for some of the samples (BL1 Set 1, PX6 Set 5), all of the mercury was probably removed in the impingers since the amount of mercury in the last impinger was essentially zero. For most of the others, it appears that not all the mercury was absorbed. However, the amount of mercury in the offgas was probably not more than about $10 \%$ higher than measured. The lower than expected efficiency for the PX6 samples was probably caused by using too high a gas sampling rate. Nonetheless, the results are adequate for determining the effectiveness of mercury removal. 
WSRC-RP-94-1141, Rev. 0

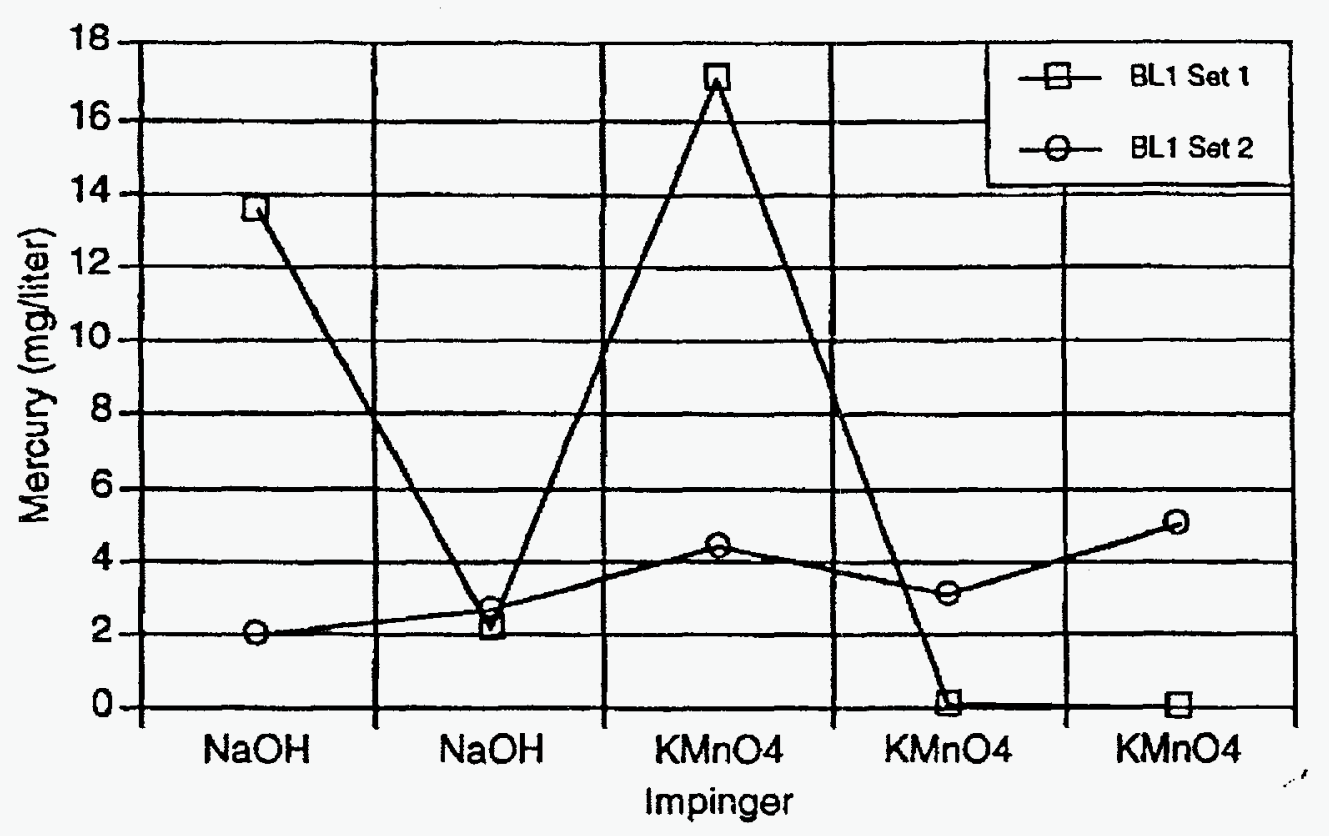

Figure 1. Concentrations of Mercury in BL1 Impinger Samples.

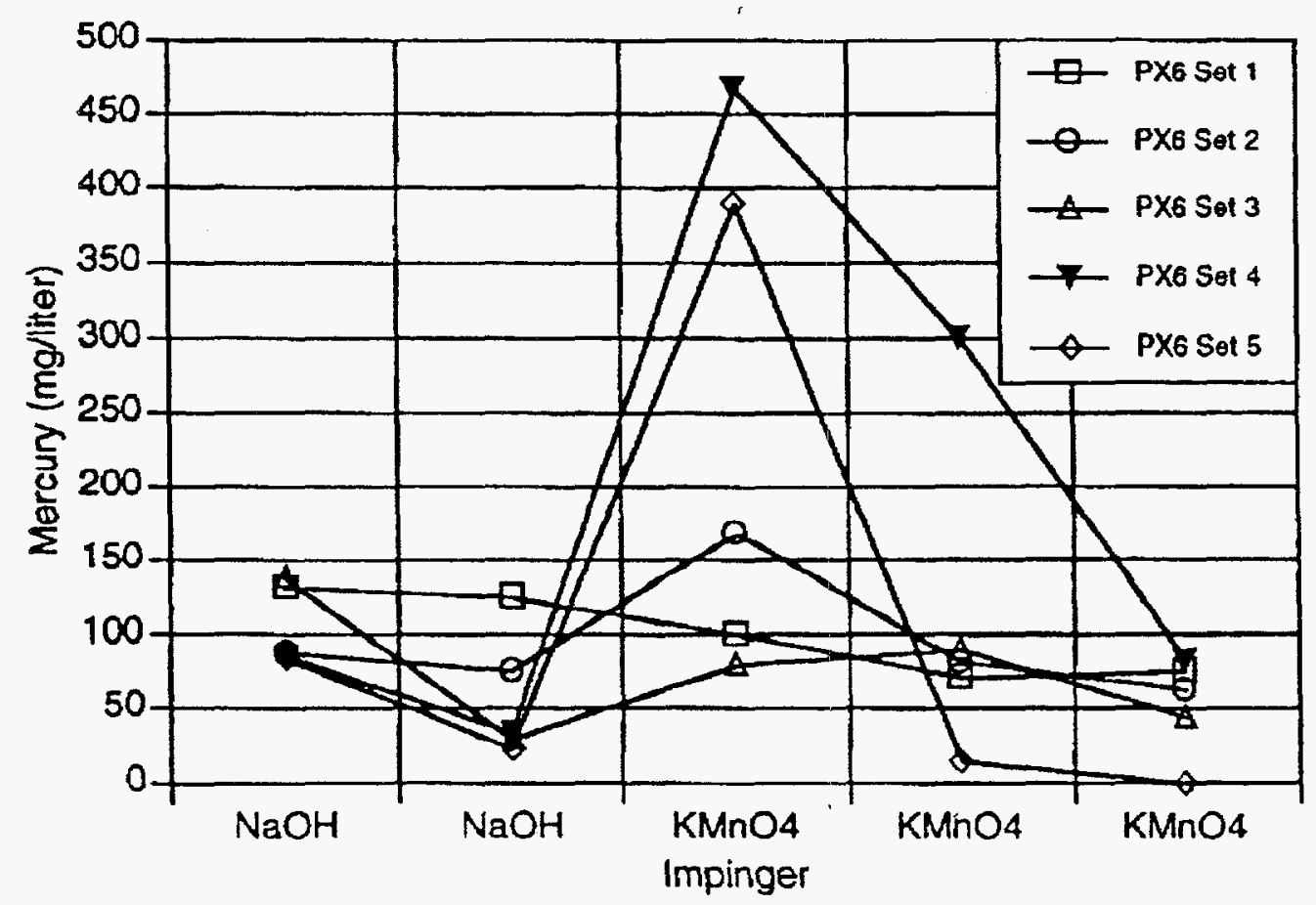

Figure 2. Concentrations of Mercury in PX6 Impinger Samples. 


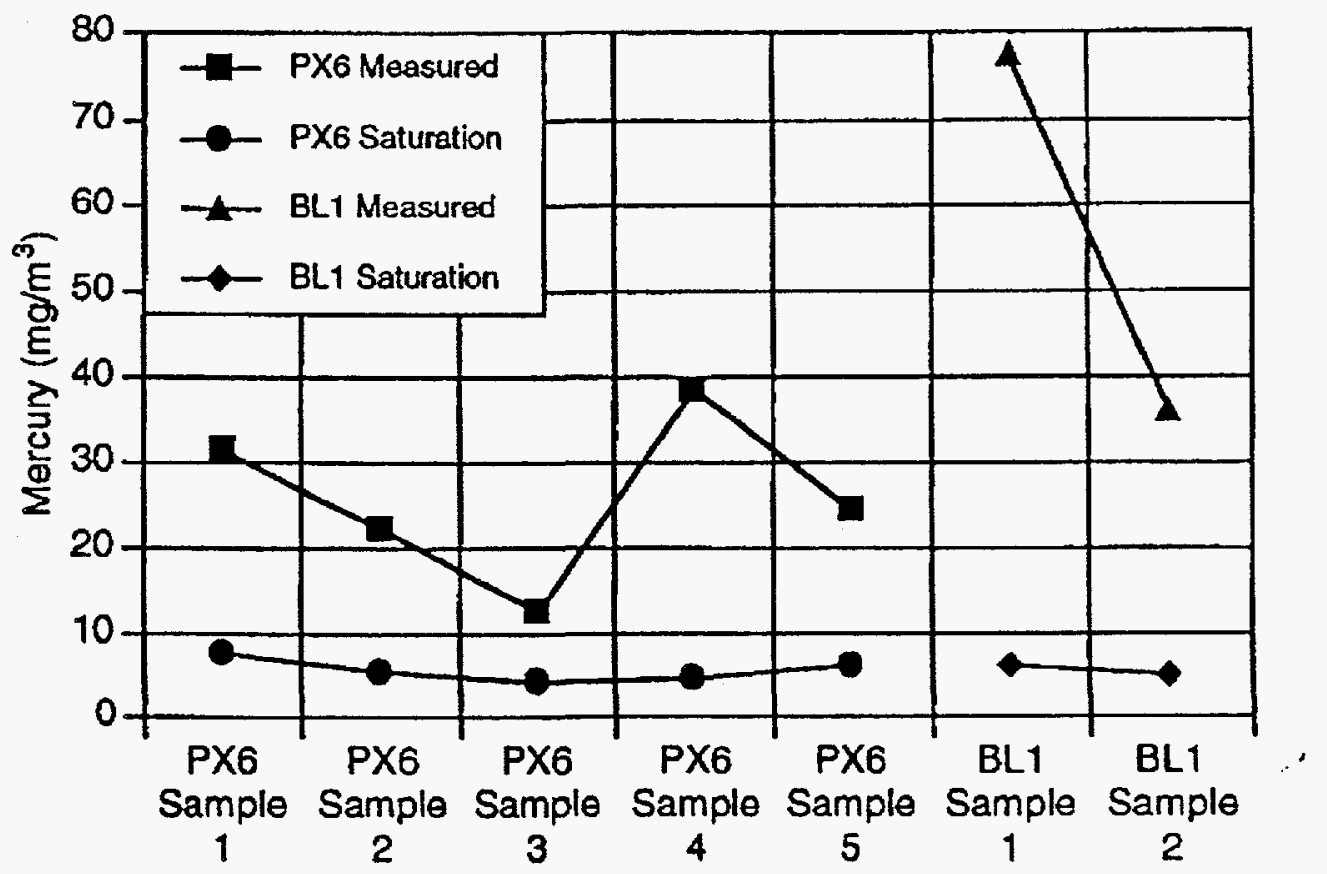

Figure 3. Mercury Concentration at the FAVC Exit.

The total amount of mercury absorbed by the impinger train was calculated from the analyses of the individual impingers. This information combined with the volume of gas sampled was then used to determine the concentration of mercury in the gas sample (see Appendix A). Figure 3 shows the concentration of mercury measured and the concentration of mercury that would have existed if the gas had been saturated with mercury at the FAVC exit temperature.

The data clearly show that the concentration of mercury exiting the FAVC (without HEME or ammonia scrubbers) is greater than the amount that would be found if the vapor were saturated, indicating that the vapor was supersaturated with mercury (or supercooled with respect to mercury). The HEME and ammonia scrubber may further reduce the mercury concentration if the supersaturated mercury is present as a mist.

Table 1 shows the condenser exit temperatures, measured and saturation concentrations, and the amount of supercooling of the offgas with respect to the measured mercury concentration. Lee 7 predicts that the vapor exiting a condenser will be supersaturated with mercury if the inlet vapor is supercooled. Lee also predicts that if the inlet relative humidity of water is less than saturation, the outlet vapor will be even more supersaturated with mercury. The FAVC inlet molar relative humidities for BL1 and PX6 were approximately $80 \%$ and $60-75 \%$. The data below show that supercooling occurs at both the exits of the SRAT condenser and the FAVC.

The ratio of the measured mercury to saturation mercury concentrations at the FAVC exit averaged 6.2. The calculation of the projected mercury emissions from the Chemical 
Process Cell is $21.2-59.0 \mathrm{lb} / \mathrm{yr}^{1}{ }^{1}$ If the mercury concentration were $6.2 \mathrm{X}$ that assumed, the emissions from the CPC would be $131-366 \mathrm{lb} / \mathrm{yr}$, which would exceed the permit level of $175 \mathrm{lb} / \mathrm{yr}$.

Table 1. Measured and Saturation Mercury Concentrations.

\begin{tabular}{|lcccccc|}
\hline Sample & $\begin{array}{c}\text { Mean } \\
\text { Temp. } \\
\left({ }^{\circ} \mathrm{C}\right)\end{array}$ & $\begin{array}{c}\text { Mercury } \\
\text { Measured } \\
\left(\mathrm{mg}^{\mathrm{m}} / \mathrm{m}^{3}\right)\end{array}$ & $\begin{array}{c}\text { Mercury at } \\
\text { Saturation } \\
\left(\mathrm{mg} / \mathrm{m}^{3}\right)\end{array}$ & $\begin{array}{c}\text { Mercury } \\
\text { Measured } \\
\text { Saturation }\end{array}$ & $\begin{array}{c}\text { Saturation } \\
\text { Temp. } \\
\left({ }^{\circ} \mathrm{C}\right)\end{array}$ & $\begin{array}{c}\text { Supercooling } \\
\left({ }^{\circ} \mathrm{C}\right)\end{array}$ \\
\hline FAVC Out: & & & & & & \\
BL1 Set 1 & $11.07^{\mathrm{a}}$ & 77.5 & 6.1 & 12.7 & 43.0 & 31.9 \\
BL1 Set 2 & $8.05^{\mathrm{a}}$ & 36.0 & 4.9 & 7.3 & 32.9 & 24.3 \\
PX6 Set 1 & $13.48^{\mathrm{b}}$ & 31.5 & 7.5 & 4.2 & 30.9 & 17.4 \\
PX6 Set 2 & $9.62^{\mathrm{b}}$ & 22.0 & 5.3 & 4.2 & 26.6 & 17.0 \\
PX6 Set 3 & $7.42^{\mathrm{b}}$ & 12.3 & 4.4 & 2.8 & 19.5 & 12.0 \\
PX6 Set 4 & $7.86^{\mathrm{b}}$ & 38.5 & 4.6 & 8.4 & 33.7 & 25.8 \\
PX6 Set 5 & $10.95^{\mathrm{b}}$ & 24.3 & 6.0 & 4.1 & 27.7 & $16.8^{\prime}$ \\
SRATC Out: & & & & & & \\
BL1 Set 1 & 36.8 & $539.6^{\mathrm{c}}$ & 49.4 & 10.9 & 73.0 & 36.2 \\
BL1 Set 2 & 30.77 & $285.3^{\mathrm{c}}$ & 31.2 & 9.1 & 62.4 & 31.7 \\
\hline
\end{tabular}

a calculated from FAVC HEME exit temperature (210TT) using offgas temperature models (see Appendix A). ${ }^{8}$

b measured FAVC tube exit temperature (170TT).

c calculated from FAVC inlet measurement and offgas flowrates (see Appendix A).

However, none of the data given here was taken with the offgas flowing through FAVC HEME. Use of the HEME would be expected to improve mercury removal if the mercury exists as a mist. Also, the ammonia scrubbers on the SRAT and SME, which operate with $\mathrm{pH} 1-3$ nitric acid, should remove some mercury from the offgas.

\section{CONCLUSIONS}

1. The Formic Acid Vent Condenser, without a HEME, does not reduce the concentration of mercury to saturation at the condenser exit temperature.

2. The SRAT (or SME) condenser also does not reduce the concentration of mercury to saturation at the condenser exit temperature.

3. Supercooling of mercury in the condenser exit vapor occurs as predicted by Lee. 
WSRC-RP-94-1141, Rev. 0

\section{RECOMMENDATIONS}

1. Perform an IDMS run with the FAVC HEME in place to determine its effect on mercury removal.

The PX7 run will be done with the HEME in place. The FAVC exit offgas will be sampled and analyzed for mercury.

2. Determine whether the ammonia scrubbers will remove mercury.

In PX7, the vapor exiting the scrubber will be sampled and analyzed for mercury.

3. The gas sampling rate should be approximately $0.1 \mathrm{cfm}$ so that the absorber efficiency approaches $99 \%$.

This rate will be used during PX7.

\section{REFERENCES}

1. Jacobs, R. A., Bounding Estimate of DWPF Mercury Emissions (U), WSRC-RP-92-1205, Rev. 2, November 15, 1993.

2. Driscoll, J. N., Sampling and Analytical Techniques for Mercury in Stationary Sources: A State-of-the-Art Report, Health Lab. Sci., 11(4), p. 348 (1974).

3. McQuaker, N. R., Sandberg, D. K., The Determination of Mercury Source Emissions in the Presence of High Levels of $\mathrm{SO}_{2}$, J. Air Poll. Cont. Assoc, 32(6), p. 634 (1982).

4. Makris, W. E., Crawford, C. J., Miller, R. O., Bell, Z. G., Jr., The Comparison of Five Published Methods for the Determination of Mercury-In-Air, Jt. Conf. Sens. Environ. Pollut., (Conf. Proc., 4th), p. 192 (1978).

5. Shendrikar, A. D., Briden, F. E., Mercury Atmosphere Generation and Media Collection Efficiency Evaluations for the SASS Impinger System, Specialty Conf. on: Measurement and Monitoring of Non-Criteria (Toxic) Contaminants in Air, Frederick, E. R. (ed.), Chicago IL, Mar. 22-24, 1983.

6. Method 111. Determination of Particulate and Gaseous Mercury Emissions From Sewage Sludge Incinerators, Federal Register, Doc. 80-31822, October 15, 1980. 
WSRC-TR-93-1141, Rev. 0

7. Lee, L. M., Mercury Removal at the Melter Off-Gas Condenser, DPST-85-799, October 15, 1985.

8. Zamecrik, J. R. The Effect of Nitric Oxide Oxidation on the DWPF Formic Acid Vent Condenser (FAVC) Exit Temperature (U), WSRC-RP-92-1174, October 29, 1992. 


\section{APPENDIX}

\section{SATURATION VAPOR PRESSURE OF MERCURY}

$$
\mathrm{p}_{\mathrm{H}_{\mathrm{g}}}^{\text {sat }}=\exp \left(18.072-\frac{7079.256}{\mathrm{~T}+265.47}\right)
$$

where $\mathrm{P}_{\mathrm{H}_{\mathrm{B}}}^{\mathrm{ant}}=$ torr

$\mathrm{T} \equiv{ }^{\circ} \mathrm{C}$

\section{ANALYSIS OF MERCURY SAMPLING DATA}

See attached sheets.

\section{ESTIMATIONOFEAVC TUBE EXIT TEMPERATURE}

For the BL1 data, the FAVC HEME exit temperature was calculated by using models developed to predict the temperature rise in the FAVC due to NO oxidation (see reference 8):

$$
T_{\text {HEMB }}=2.9171\left[\mathrm{NO}_{x}\right]^{0.5681}+3.7210 \beta\left[\mathrm{NO}_{x}\right]^{0.3331}+\mathrm{T}_{\text {amb }}+\mathrm{T}_{\mathrm{c}}+\mathrm{T}_{\text {app }}
$$

where $\mathrm{T}_{\mathrm{HEME}}=$ FAVC HEME exit temperature $\left({ }^{\circ} \mathrm{C}\right)$

$T_{\mathrm{c}}=$ average cooling water temperature (inlet \& outlet) $\left({ }^{\circ} \mathrm{C}\right)$

$\mathrm{T}_{\text {app }}=$ approach temperature $\left({ }^{\circ} \mathrm{C}\right) \approx 1.6$

$T_{a m b}=$ temperature rise from tube exit to HEME exit due to ambient heat conduction $\left({ }^{\circ} \mathrm{C}\right)$

$\left[\mathrm{NO}_{\mathrm{x}}\right]=$ concentration of $\mathrm{NO}_{\mathrm{x}}$ at FAVC exit (mol \%)

$\beta=$ bypassing factor ( $=0$ if HEME bypassed; $=1$ if HEME not bypassed)

The predicted and measured FAVC HEME exit temperatures are shown in Figure A-1. Since the data fit well, estimation of the tube exit temperature using the models was deemed appropriate.

The FAVC tube exit temperature was estimated as:

$$
T_{\text {tube }}=2.9171\left[\mathrm{NO}_{\mathrm{x}}\right]^{0.5681}+\mathrm{T}_{\mathrm{c}}+\mathrm{T}_{\text {app }}
$$

where $T_{\text {tube }}=$ FAVC tube exit temperature $\left({ }^{\circ} \mathrm{C}\right)$

$\mathrm{T}_{\mathrm{c}}=$ average cooling water temperature (inlet \& outlet) $\left({ }^{\circ} \mathrm{C}\right)$

$\mathrm{T}_{\mathrm{app}}=$ approach temperature $\left({ }^{\circ} \mathrm{C}\right)=1.6$

$$
\left[\mathrm{NO}_{\mathrm{x}}\right]=\text { concentration of } \mathrm{NO}_{\mathrm{x}} \text { at } \mathrm{FAVC} \text { exit }(\mathrm{mol} \%)
$$

The predicted FAVC tube exit temperature is also shown in Figure A-1. 


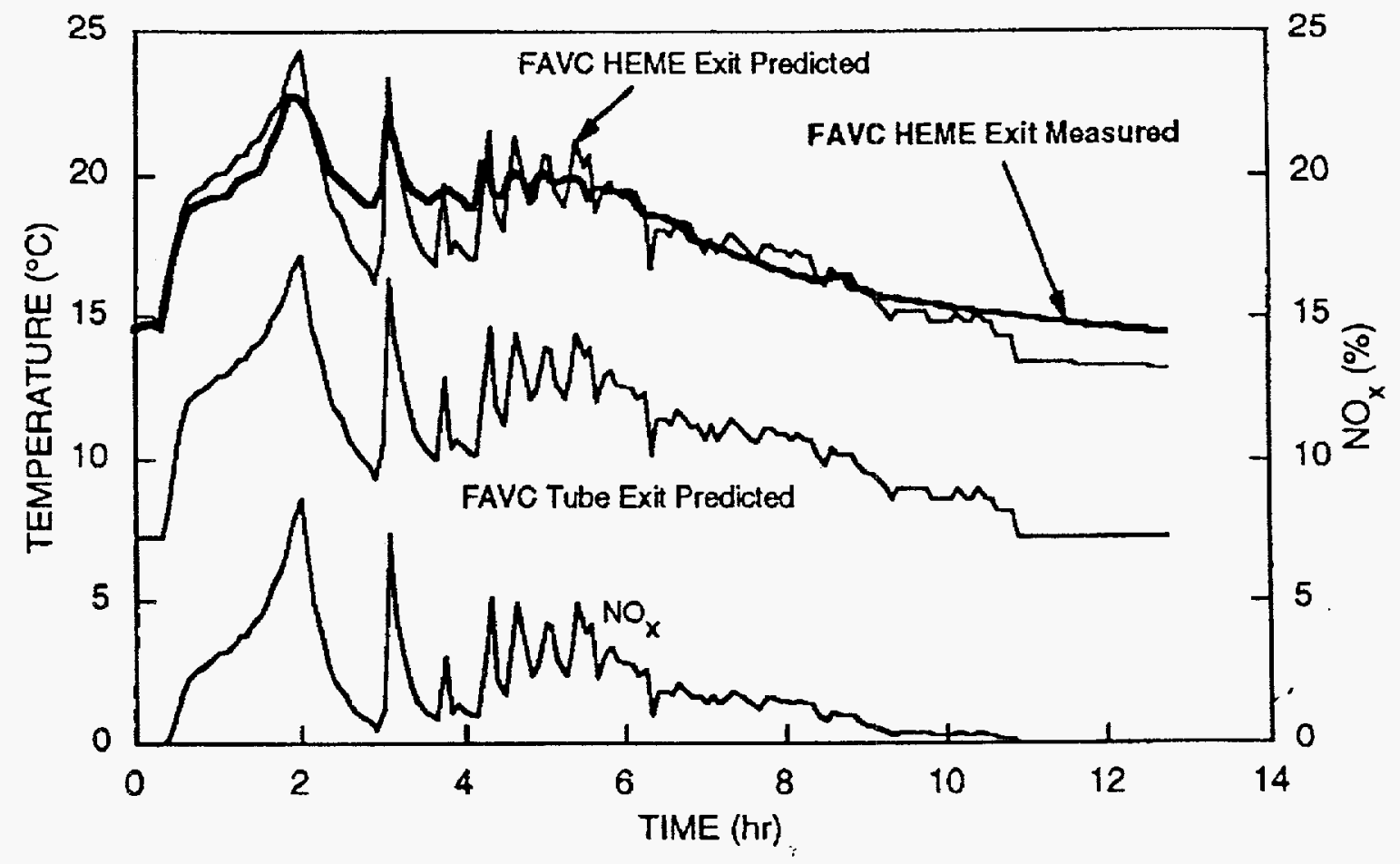

Figure A-1. Measured and Predicted FAVC Temperatures 
IDMS RUN: PUAEX 6

COMMENTS MERCURY SAMPLING SETI

DATE: $12 / 7 / 93$

TIME: 13:55 PM - 19:00 PM

WASHED SAMPLE:

IDMS \# ID-RUN-IMPI-

\begin{tabular}{|c|c|c|c|c|c|}
\hline & & & & & \\
\hline & 7420 & \multicolumn{2}{|c|}{\begin{tabular}{|l|l|}
7421 & 7422 \\
\end{tabular}} & 7423 & 7424 \\
\hline & $\mathrm{NaOH}$ & $\mathrm{NaOH}$ & $\mathrm{KMnO} 4$ & $\mathrm{KMnO4}$ & $\mathrm{KMnO4}$ \\
\hline Empty bottle & 38.76 & 39.13 & 38.10 & 38.24 & 39.05 \\
\hline Sample + wash water & 413.28 & 498.34 & 178.25 & 112.01 & 88.95 \\
\hline
\end{tabular}

Weight of sample Approx. density of sample Volume of sample

\begin{tabular}{|r|r|r|r|r|r|}
\hline$g$ & 374.52 & 459.21 & 140.15 & 73.77 & 49.90 \\
\hline $\mathrm{g} / \mathrm{m} /$ & 1.10 & 1.10 & 1.10 & 1.10 & 1.10 \\
\hline $\mathrm{ml}$ & 340.5 & 417.5 & 127.4 & 67.1 & 45.4 \\
\hline
\end{tabular}

\begin{tabular}{|l|l|l|l|l|l|l|} 
Conc of $\mathrm{Hg}$ & mgliter (ppm) & 132.0 & 125.0 & 100.0 & 71.4 & 75.2 \\
\hline
\end{tabular}

\begin{tabular}{rr|r|r|r|r|r|} 
Hg collected & $\mathrm{mg}$ & 44.9 & 52.2 & 12.7 & 4.8 & 3.4 \\
\cline { 2 - 7 } & \% of total collected & 38.07 & 44.20 & 10.79 & 4.06 & 2.89 \\
\hline
\end{tabular}

Tolal Hg collectod $\square \quad \mathrm{mg} \quad 118.1$

DRY GAS SAMPLE:

Gas Volume cu ft 132.50

MEASURED MERCURY CONCENTRATION:

\begin{tabular}{|c|c|c|c|}
\hline $\mathrm{Hg}$ concentration [ & ug/t3 & 891.06 & \\
\hline $\mathrm{Hg}$ concentration & $g / m 3$ & 0.0315 & \\
\hline $\mathrm{Hg}$ concentration & ppm by vol & 3.690 & (assuming $1 \mathrm{~atm}$ pressure) \\
\hline Saturalion temp & ${ }^{\circ} \mathrm{C}$ & 30.90 & \\
\hline Subcooling of $\mathrm{Hg}$ & ${ }^{\circ} \mathrm{C}$ & 17.42 & \\
\hline
\end{tabular}

MERCURY CONCENTRATION AT SATURATION (PROCESS BASIS) :

\begin{tabular}{|c|c|c|}
\hline Average Temperature & ${ }^{\circ} \mathrm{C}$ & 13.48 \\
\hline $\mathrm{Hg}$ concentratlon & ug/t33 & 213.3 \\
\hline $\mathrm{Hg}$ concentration & $\alpha / \mathrm{m} 3$ & 0.0075 \\
\hline $\mathrm{Hg}$ concentration & pom by voll & 0.883 \\
\hline
\end{tabular}


IDMS RUN: PUREX 6

COMMENTS MERCURY SAMPLING SET2

DATE: $12 / 7 / 1993-12 / 8 / 93$

TIME: 19:10 PM - 00:15 AM

WASHED SAMPLE:

IDMS \# ID-RUN-IMPI-

\begin{tabular}{|c|c|c|c|c|c|c|}
\hline & & & & & \\
\hline & & 7425 & 7426 & 7427 & 7428 & 7429 \\
\hline & & $\mathrm{NaOH}$ & $\mathrm{NaOH}$ & KMnO4 & KMnO4 & $\mathrm{KMnO} 4$ \\
\hline Emply bottle & g] & 38.84 & 39.01 & 38.81 & 38.75 & 38.93 \\
\hline Sample + wash water & g. & 225.93 & 254.33 & 312.51 & 268.77 & 270.36 \\
\hline
\end{tabular}

\begin{tabular}{|r|r|r|r|r|r|r|}
\hline Welght of sample & 9 & 187.09 & 215.32 & 273.70 & 230.02 & 231.43 \\
\cline { 2 - 7 } Approx. density of sample & $\mathrm{g} / \mathrm{m} /$ & 1.1 & 1.1 & 1.1 & 1.1 & 1.1 \\
\hline Volume of sample & $\mathrm{m}$ & 170.1 & 195.7 & 248.8 & 209.1 & 210.4 \\
\hline
\end{tabular}

\begin{tabular}{|c|c|c|c|c|c|c|}
\hline Conc of $\mathrm{Hg}$ & mgliter (ppm) & 87.2 & 75.4 & 169.0 & $81.1]$ & 62.7 \\
\hline
\end{tabular}

\begin{tabular}{r|r|r|r|r|r|r|}
\hline $\mathrm{Hg}$ collected & $\mathrm{mg}$ & 14.83 & 14.76 & 42.05 & 16.96 & 13.19 \\
\hline$\%$ of total collected & $\%$ & 14.57 & 14.50 & 41.31 & 16.66 & 12.96 \\
\hline
\end{tabular}

Total Hg collected $\begin{array}{r}\quad \mathrm{mg} \\ \hline\end{array}$

DRY GAS SAMPLE:

Gas Volume cu frr 163.20

MEASURED MERCURY CONCENTRATION:

\begin{tabular}{rr|r|}
$\mathrm{Hg}$ concentration & $\mathrm{ug} / \mathrm{H} 3$ & 623.72 \\
\cline { 2 - 3 } $\mathrm{Hg}$ concentration & $\mathrm{g} / \mathrm{m} 3$ & 0.0220 \\
Sa concentration & ppm by vol & 2.548 \\
\cline { 2 - 3 } Saturation temp & (assuming 1 alm pressure) \\
Subcoolling of $\mathrm{Hg}$ & ${ }^{\circ} \mathrm{C}$ & 26.59 \\
\hline${ }^{\circ} \mathrm{C}$ & 16.97 \\
\hline
\end{tabular}

MERCURY CONCENTRATION AT SATURATION (PROCESS BASIS) :

\begin{tabular}{|c|c|c|}
\hline Average Temperature & ${ }^{\circ} \mathrm{C}$ & 9.62 \\
\hline $\mathrm{Hg}$ concentration & ug/fit3 & 151.5 \\
\hline $\mathrm{Hg}$ concentration & $g^{\prime m 3}$ & 0.0053 \\
\hline $\mathrm{Hg}_{\mathrm{g}}$ concentration [ & ppm by vol & 0.619 \\
\hline
\end{tabular}


IDMS RUN: PUREX 6

COMMENTS MERCURY SAMPLING SET 3

DATE: $12 / 8 / 93$

TIME: 00:23 AM - 5:30 AM

WASHED SAMPLE:

IDMS \# ID-RUN-IMPI-

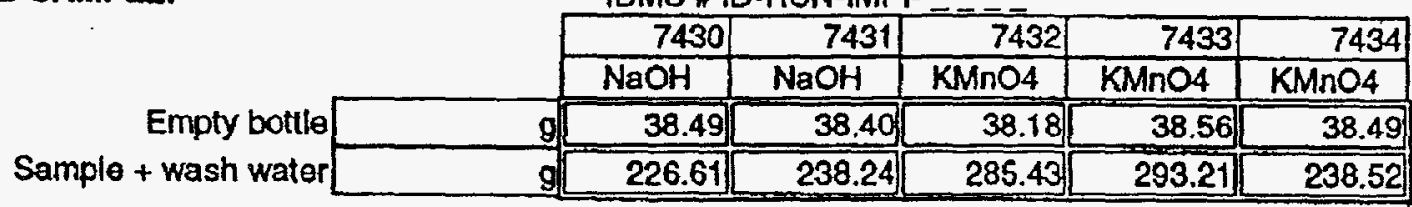

\begin{tabular}{rr|r|r|r|r|r|} 
Weight of sample & 9 & 188.12 & 199.84 & 247.25 & 254.65 & 200.03 \\
\cline { 2 - 6 } & $\mathrm{g} / \mathrm{ml}$ & 1.1 & 1.1 & 1.1 & 1.1 & 1.1 \\
\hline Approx. density of sample & $\mathrm{ml}$ & 171.0 & 181.7 & 224.8 & 231.5 & 181.8 \\
\hline
\end{tabular}

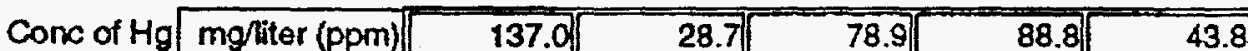

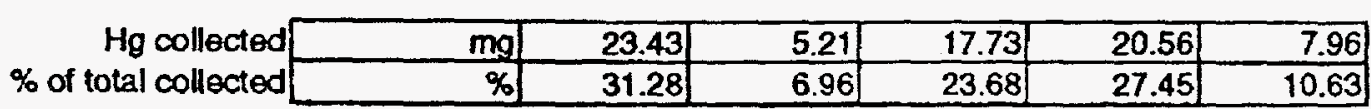

Total $\mathrm{Hg}$ collected

$\mathrm{mg} \quad \mathbf{7 4 . 9 0}$

DRY GAS SAMPLE:

Gas Volume cu 215.60

MEASURED MERCURY CONCENTRATION:

\begin{tabular}{|c|c|c|}
\hline $\mathrm{Hg}$ concentration & ug/ft3 & 347.40 \\
\hline $\mathrm{Hg}$ concentration & $g / m 3$ & 0.0123 \\
\hline Hg concentration & ppm by vol & 1.408 (assuming 1 atm pressure) \\
\hline Saturation temp & ${ }^{\circ} \mathrm{C}$ & 19.46 \\
\hline Subcooling of $\mathrm{Hg}$ & ${ }^{\circ} \mathrm{C}$ & 12.04 \\
\hline
\end{tabular}

MERCURY CONCENTRATION AT SATURATION (PROCESS BASIS) :

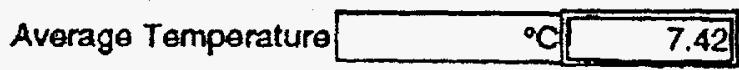

\begin{tabular}{|c|c|c|}
\hline $\mathrm{Hg}$ concentration & ug/t3 & 124.0 \\
\hline $\mathrm{Hg}$ concentration & $\mathrm{g} / \mathrm{m} 3$ & 0.0044 \\
\hline $\mathrm{Hg}$ concen & ppm by voll & 0.503 \\
\hline
\end{tabular}


IDMS RUN: PUREX 6

COMMENTS MERCURY SAMPLING SET 4

DATE: $12 / 8 / 93$

TIME: 06:15 AM - 11:20 AM

WASHED SAMPLE:

IDMS \# ID-RUN-IMPI-

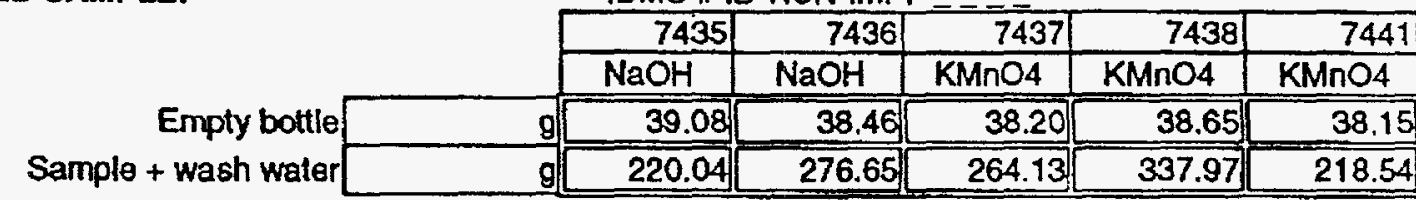

\begin{tabular}{|c|c|c|c|c|c|c|}
\hline Welght of sample & g & 180.96 & 238.19 & 225.93 & 299.32 & 180.39 \\
\hline prox. den & $\mathrm{g} / \mathrm{m}$ & 1.1 & 1.1 & 1.1 & 1.1 & 1.1 \\
\hline Volume of & $\mathrm{ml}$ & 164.5 & 216.5 & 205.4 & 272.1 & 164.0 \\
\hline
\end{tabular}

\begin{tabular}{llllllllll} 
Conc of $\mathrm{Hg}$ & mgliter (ppm) & 86.2 & 32.5 & 467.0 & 301.0 & 82.0 \\
\hline
\end{tabular}

\begin{tabular}{r|r|r|r|r|r|r|} 
Hg collected & $\mathrm{mg}$ & $\mathbf{1 4 . 1 8}$ & 7.04 & 95.92 & 81.90 & 13.45 \\
\hline \% of total collected & $\%$ & 6.67 & 3.31 & 45.14 & 38.55 & 6.33 \\
\hline
\end{tabular}

Total $\mathrm{Hg}$ collected

\begin{tabular}{l|l|}
$\mathrm{mg}$ & 212.49 \\
\hline
\end{tabular}

DRY GAS SAMPLE:

Gas Volume cu 1900

MEASURED MERCURY CONCENTRATION:

\begin{tabular}{|c|c|c|}
\hline $\mathrm{Hg}$ concentration & ug/t3 & 1089.68 \\
\hline $\mathrm{Hg}$ concentration & $g / \mathrm{m}^{3}$ & 0.0385 \\
\hline $\mathrm{Hg}$ concentration & ppm by voll & 4.424 \\
\hline Saturation temp & ${ }^{\circ} \mathrm{C}$ & 33.68 \\
\hline
\end{tabular}

\section{MERCURY CONCENTAATION AT SATURATION (PROCESS BASIS) :}

\begin{tabular}{l} 
Average Temperature \\
\cline { 2 - 3 } \\
Hg concentration
\end{tabular}


IDMS RUN: PUREX 6

COMMENTS MERCURY SAMPLING SET 5

DATE: $12 / 8 / 93$

TIME: 11:37 AM - 16:35 PM

WASHED SAMPLE:

IDMS \# ID-RUN-IMPI-

\begin{tabular}{|c|c|c|c|c|c|}
\hline & \multirow{2}{*}{7442} & \multirow{2}{*}{7443} & \multirow{2}{*}{7444} & \\
\hline & & & & 7445 & 7446 \\
\hline & $\mathrm{NaOH}$ & $\mathrm{NaOH}$ & $\mathrm{KMnO} 4$ & $\mathrm{KMnO} 4$ & $\mathrm{KMnO} 4$ \\
\hline Empty bottle & 38.15 & 38.82 & 38.87 & 38.47 & 38.77 \\
\hline Sample + wash water & 262.54 & 255.35 & 286.40 & 258.90 & 260.55 \\
\hline
\end{tabular}

\begin{tabular}{|c|c|c|c|c|c|c|}
\hline Weight of sample & g & 224.39 & 216.53 & 247.53 & 220.43 & 221.78 \\
\hline prox. den & $g / m$ & 1.1 & 1.1 & 1.1 & 1.1 & 1.1 \\
\hline Volume of & $\mathrm{ml}$ & 204.0 & 196.8 & 225.0 & 200.4 & 201.6 \\
\hline
\end{tabular}

\begin{tabular}{|c|c|c|c|c|c|}
\hline Conc of $\mathrm { Hg } \longdiv { \text { mg/iter (ppm) } }$ & 83.0 & 22.4 & 391.0 & 14.0 & 1.0 \\
\hline
\end{tabular}

\begin{tabular}{r|r|r|r|r|r|r|}
\hline $\mathrm{mg}$ collected & $\mathrm{mg}$ & 16.931 & 4.409 & 87.986 & 2.805 & 0.204 \\
\hline \% of total collected & $\%$ & 15.07 & 3.93 & 78.32 & 2.50 & 0.18 \\
\hline
\end{tabular}

Total $\mathrm{Hg}$ collected $\quad \mathrm{mg} \quad 112.34$

DRY GAS SAMPLE:

Gas Volume cu ft 163.50

MEASUAED MERCURY CONCENTRATION:

\begin{tabular}{|c|c|c|c|}
\hline $\mathrm{Hg}$ concentration & ug/tia & 687.07 & \\
\hline Hg concentration & $g / m 3$ & 0.0243 & \\
\hline Hg concentration & gpm by vol & 2.820 & (assuming $1 \mathrm{~atm}$ pressure) \\
\hline Saturation temp & ${ }^{\circ} \mathrm{C}$ & 27.72 & \\
\hline Subcooling of $\mathrm{H}$ & ${ }^{\circ} \mathrm{C}$ & 16.77 & \\
\hline
\end{tabular}

\section{MERCURY CONCENTRATION AT SATURATION (PROCESS BASIS) :}

\begin{tabular}{|c|c|c|}
\hline Average Temperature & ${ }^{\circ} \mathrm{C}[$ & 10.95 \\
\hline Hg concentration & ugft3 & 170.6 \\
\hline $\mathrm{Hg}$ concentration & $g / m 3$ & 0.0060 \\
\hline Hg concentration & ppm by vol & 0.700 \\
\hline
\end{tabular}


IDMS RUN: BLI

COMMENTS FORMIC REFLUX I FAVC IN

DATE: $6 / 20 / 90$

TIME: 22:00-23:00

WASHED SAMPLE:

IDMS * ID-RUN-IMPI-

\begin{tabular}{|c|c|c|c|c|c|}
\hline & 3378 & 3379 & 3380 & 3381 & 3392 \\
\hline & $\mathrm{NaOH}$ & $\mathrm{NaOH}$ & $\mathrm{KMnO4}$ & $\mathrm{KMnO4}$ & $\mathrm{KMnO} 4$ \\
\hline Empty bottle & 68.80 & 68.40 & 69.80 & 69.00 & 68.60 \\
\hline Sample + wash water & 662.70 & 438.60 & 303.00 & 538.20 & 404.30 \\
\hline
\end{tabular}

\begin{tabular}{|c|c|c|c|c|c|c|}
\hline Welght of sample & g & 427.3 & 414.1 & 545.3 & 480.7 & 358.9 \\
\hline iprox. density 0 & gimll & 1.10 & 1.10 & 1.10 & 1.10 & 1.10 \\
\hline Volume of sample & $\mathrm{ml}$ & 388.5 & 376.5 & 495.7 & 437.0 & 326.3 \\
\hline
\end{tabular}

\begin{tabular}{|c|c|c|c|c|c|}
\hline Cone of $\mathrm{Hg}$ & mg/iter (ppm) & 31.30 & 4.30 & 39.00 & 0.26 \\
\hline
\end{tabular}

\begin{tabular}{rr|r|r|r|r|r|} 
Hg collected & $\mathrm{mg}$ & 12.2 & 1.6 & 19.3 & 0.1 & 0.0 \\
\hline$\%$ of total collected & $\%$ & 36.58 & 4.87 & 58.16 & 0.34 & 0.05 \\
\hline
\end{tabular}

\begin{tabular}{lr} 
Total $\mathrm{Hg}$ collected \\
\hline
\end{tabular}

DRY GAS SAMPLE:

Gas Volume cu $\quad 3.70$

MEASURED MERCURY CONCENTRATION AT FAVC INLET:

\begin{tabular}{|c|c|c|c|}
\hline $\mathrm{Hg}$ concentration & ug/ti3 & 8993.97 & \\
\hline Hg concentration & $g / \mathrm{m} 3$ & 0.3173 & \\
\hline $\mathrm{Hg}$ concentration & ppm by vol & 40.227 & (assuming 1 atm pressure \\
\hline Saturation le & ${ }^{\circ} \mathrm{C}$ & 64,20 & \\
\hline
\end{tabular}

\section{MERCURY CONCENTRATION AT SAAT CONDENSER EXIT:}

\begin{tabular}{r|r|r|}
\multicolumn{2}{|c|}{ SRATC exut flow / Total flow } & 0.588 \\
\cline { 2 - 3 } $\mathrm{Hg}$ concentratton & $\mathrm{ug} / \mathrm{tt}$ & $\mathbf{1 5 2 7 8 . 8 6}$ \\
$\mathrm{Hg}$ concentration & $\mathrm{g} / \mathrm{m} 3$ & 0.5396 \\
$\mathrm{Hg}$ concentration & $\mathrm{ppm}$ by vol & 68.413 \\
\cline { 2 - 3 } Saturation temp & ${ }^{\circ} \mathrm{C}$ & 72.95 \\
\hline Subcooling of $\mathrm{Hg}$ & ${ }^{\circ} \mathrm{C}$ & 36.15 \\
\hline
\end{tabular}

MERCURY CONCENTRATION AT SATURATION (SRAT CONDENSER EXT) :

\begin{tabular}{|c|c|c|}
\hline Average Temperature & ${ }^{\circ} \mathrm{C}[$ & 36.80 \\
\hline $\mathrm{Hg}$ concentration & $\mathrm{ug} / \mathrm{ft} 3$ & 1397.6 \\
\hline Hg concentration & $g / m 3$ & 0.0494 \\
\hline Hg concentration & ppm by vol & 6.258 \\
\hline
\end{tabular}


IDMS RUN: BL1

COMMENTS FOPIMIC REFLUX 2 FAVC IN

DATE: $6 / 21 / 90$

TIME: 01:00-02:00

WASHED SAMPLE:

IDMS \# ID-RUN-IMPI-

\begin{tabular}{|c|c|c|c|c|c|c|}
\hline & & \multicolumn{2}{|c|}{\begin{tabular}{|r|r|}
3395 & 3396 \\
\end{tabular}} & \multirow{2}{*}{$\begin{array}{r}3397 \\
\mathrm{KMnO4}\end{array}$} & 3398 & 3399 \\
\hline & & $\mathrm{NaOH}$ & $\mathrm{NaOH}$ & & KMnO4 & $\mathrm{KMnO4}$ \\
\hline Empty bottle & g & 68.80 & 68.70 & 68.50 & 68.40 & 69.10 \\
\hline Sample + wash water & $\mathrm{g}$ & 474.70 & 500.90[ & 480.70 & 593.80 & 347.70 \\
\hline
\end{tabular}

\begin{tabular}{|c|c|c|c|c|c|c|}
\hline Welght of sample & $\mathrm{g}$ & 427.3 & 414.1 & 545.3 & 480.7 & 358.9 \\
\hline pprox. density of sample & $g / \mathrm{m}$ & 1.10 & 1.10 & 1.10 & 1.10 & 1.10 \\
\hline Volume of sample & $\mathbf{m i}$ & 388.5 & 376.5 & 495.7 & 437.0 & 326.3 \\
\hline
\end{tabular}

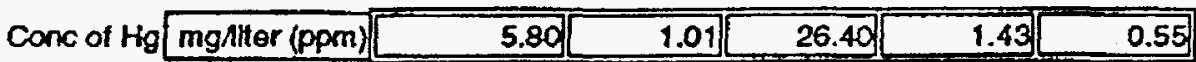

\begin{tabular}{|c|c|c|c|c|c|c|}
\hline & $\mathrm{mg}$ & 2.3 & 0.4 & 13.1 & 0.6 & 0.2 \\
\hline of tota & $\%$ & 13.63 & 2.30 & 79.20 & 3.78 & 1.09 \\
\hline
\end{tabular}

Total Hg collected $\quad \mathrm{mg} \quad 16.5$

DRY GAS SAMPLE:

Gas volume $\quad$ cut $\square .10$

MEASURED MERCURY CONCENTAATION AT FAVC INLET:

\begin{tabular}{|c|c|c|c|}
\hline $\mathrm{Hg}$ concontration & $4 g / \pi / 3$ & 3240.16 & \\
\hline $\mathrm{Hg}$ concentration & $g / m 3$ & 0.1144 & \\
\hline $\mathrm{Hg}$ concentration & ppm by vol & 14.226 & sure) \\
\hline Saturalion temp & ${ }^{\circ} \mathrm{C}$ & 48.64 & \\
\hline
\end{tabular}

\section{MERCURY CONCENTRATION AT SRAT CONDENSER EXIT:}

\begin{tabular}{|c|c|c|}
\hline \multicolumn{2}{|c|}{ SAATC ext flow / Total flow } & 0.401 \\
\hline $\mathrm{Hg}$ concentration & $40 / \pi 3$ & 8080.20 \\
\hline $\mathrm{Hg}$ concentration & $\operatorname{gm} 3$ & 0.2853 \\
\hline Hg concentration & ppm by vol & 35.477 \\
\hline & ${ }^{\circ} \mathrm{C}$ & 62.44 \\
\hline Subcooling & ${ }^{\circ} \mathrm{C}$ & 31.67 \\
\hline
\end{tabular}

MERCURY CONCENTRATION AT SATURATION (SRAT CONDENSER EXIT) :

\begin{tabular}{|c|c|}
\hline Average Temperature & ${ }^{\circ} \mathrm{a}$ \\
\hline Hg cono & $\log / 13$ \\
\hline $\mathrm{Hg}$ cor & $g / m 3$ \\
\hline $\mathrm{Hg}$ concentration & ppm by voll \\
\hline
\end{tabular}


IDMS RUN: BL1 COMMENTS FORMIC REFLUX 1 FAVC OUT

DATE: $6 / 20 / 90$

TIME: 22:00-23:00

WASHED SAMPLE:

IDMS \# ID-RUN-IMPI-

\begin{tabular}{|c|c|c|c|c|c|c|}
\hline \multirow{3}{*}{\multicolumn{2}{|c|}{ s }} & \\
\hline & & 3385 & 3386 & 3387 & 3388 & 3389 \\
\hline & & $\mathrm{NaOH}$ & $\mathrm{NaOH}$ & $\mathrm{KMnO} 4$ & $\mathrm{KMnO} 4$ & $\mathrm{KMnO4}$ \\
\hline Empty bottle & g & 69.00 & 68.70 & 69.30 & 68.90 & 68.90 \\
\hline Sample + wash water & $g$ & 490.90 & 492.10 & 565.80 & 533.60 & 301.20 \\
\hline
\end{tabular}

\begin{tabular}{|r|r|r|r|r|r|r|}
\hline Welght of sample & 9 & 421.90 & 423.40 & 496.50 & 464.70 & 232.30 \\
\cline { 2 - 7 } & 9 Approx. density of sample & & 1.1 & 1.1 & 1.1 \\
\hline Volume of sample & $\mathrm{ml}$ & 383.5 & 384.9 & 451.4 & 422.5 & 211.2 \\
\hline
\end{tabular}

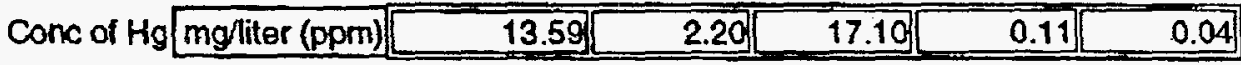

\begin{tabular}{rr|r|r|r|r|r|}
$H$ Hg collected & $\mathrm{mg}$ & 5.212 & 0.847 & 7.718 & 0.046 & 0.008 \\
\cline { 2 - 6 }$\%$ of tolal collected & $\%$ & 37.68 & 6.12 & 55.80 & 0.34 & 0.06 \\
\hline
\end{tabular}

Total Hg collected $\quad \mathrm{mg} \quad 13.8$

DRY GAS SAMPLE:

Gas Volume cu ft $\quad 6.30$

MEASURED MERCURY CONCENTRATION:

\begin{tabular}{r|r|r|}
\hline $\mathrm{Hg}$ concentration & ug/t3 & 2195.62 \\
\cline { 2 - 3 } $\mathrm{Hg}$ concentration & $\mathrm{g} / \mathrm{m} 3$ & 0.0775 \\
\cline { 2 - 3 } Hg concentration & ppm by vol & 9.015 \\
\cline { 2 - 3 } Saturation temp & ${ }^{\circ} \mathrm{C}$ & 43.01 \\
\hline Subcooling of $\mathrm{Hg}$ & ${ }^{\circ} \mathrm{C}$ & 31.94 \\
\hline
\end{tabular}

\section{MERCURY CONCENTRATION AT SATURATION (PROCESS BASIS) :}

Average Temperature ${ }^{\circ} \mathrm{C}[11.07]$ astimated

\begin{tabular}{rr|r|}
$\mathrm{Hg}$ concentralion & $\mathrm{ug} / \mathrm{ft} 3$ & 172.4 \\
\cline { 2 - 3 } $\mathrm{Hg}$ concentration & $\mathrm{g} / \mathrm{m3}$ & 0.0061 \\
\cline { 2 - 2 } $\mathrm{Hg}$ concentration & pom by vol & 0.708 \\
\hline
\end{tabular}


IDMS RUN: BL1

COMMENTS FORMIC REFLUX 2 FAVC OUT

DATE: $6 / 21 / 90$

TIME: 01:00-02:00

WASHED SAMPLE:

IDMS \# ID-RUN-IMPI-

\begin{tabular}{|c|c|c|c|c|c|c|}
\hline & & & & & & \\
\hline & & 3402 & \multicolumn{2}{|c|}{\begin{tabular}{|l|l|}
3403 & 3404 \\
\end{tabular}} & 3405 & 3406 \\
\hline & & $\mathrm{NaOH}$ & $\mathrm{NaOH}$ & $\mathrm{KMnO4}$ & $\mathrm{KMnO} 4$ & $\mathrm{KMnO} 4$ \\
\hline Empty botlle & g] & 68.90 & 68.40 & 68.60 & 68.20 & 68.60 \\
\hline Sample + wash water & $\mathrm{g}$ & 496.20 & 482.50 & 613.90 & 548.90 & 427.50 \\
\hline
\end{tabular}

\begin{tabular}{|c|c|c|c|c|c|c|}
\hline Weight of sample & $g$ & 427.3 & 414.1 & 545.3 & 480.7 & 358.9 \\
\hline prox density of sample & $\mathrm{g} / \mathrm{m}$ & 1.10 & 1.10 & 1.10 & 1.10 & 1.10 \\
\hline Volume of sample & $\mathrm{ml}$ & 388.5 & 376.5 & 495.7 & 437.0 & 326.3 \\
\hline
\end{tabular}

\begin{tabular}{|c|c|c|c|c|c|}
\hline Conc of $\mathrm { Hg } \longdiv { \mathrm { mg } / \mathrm { fter } ( \mathrm { ppm } ) }$ & 1.99 & 2.74 & 4.46 & 3.16 [ & 5.03 \\
\hline
\end{tabular}

\begin{tabular}{|c|c|c|c|c|c|c|}
\hline $\mathrm{Hg}$ collected & $\mathrm{mg}$ & 0.8 & $\begin{array}{l}1.0 \\
\end{array}$ & 2.2 & 1.4 & 1.6 \\
\hline of total & $\%$ & 10.98 & 14.66 & 31.42 & 19.62 & 23.32 \\
\hline
\end{tabular}

Total $\mathrm{Hg}$ collected $\mathrm{mg}$ 7.0

DRY GAS SAMPLE:

Gas Volume $\quad$ cu ft $\quad 6.90$

MEASURED MERCURY CONCENTRATION:

\begin{tabular}{|c|c|c|c|}
\hline $\mathrm{Hg}$ concentration & ughti3 & 1019.93 & \\
\hline Hg concentration & $\mathrm{g} / \mathrm{m} 3$ & 0.0360 & \\
\hline $\mathrm{Hg}$ concentration & ppm by vol & 4.152 & (assuming 1 atm pressure) \\
\hline Saturalion temp & ${ }^{\circ} \mathrm{C}$ & 32.90 & \\
\hline Subcooling of $\mathrm{Hg}$ & ${ }^{\circ} \mathrm{C}$ & 24.25 & \\
\hline
\end{tabular}

MERCURY CONCENTRATION AT SATURATION (PROCESS BASIS) :

\begin{tabular}{|c|c|c|}
\hline Average Temperature & ${ }^{\circ} \mathrm{C}[$ & 8.65 \\
\hline Hg concentration & ug/fi3 & 138.7 \\
\hline $\mathrm{Hg}$ concentration & $9 / \mathrm{m}^{3}$ & 0.0049 \\
\hline $\mathrm{Hg}$ concentration & pem by voll & 0.565 \\
\hline
\end{tabular}

